\title{
The problem of Junior
}

\section{Parent trap.}

\section{Swapna Kishore}

Positronic circuits, decision algorithms, laws of robotics, fuzzy logic - it wasn't just difficult, it was boring. Roy would have rather experimented with the recipe in Gourmet Fare (Clara loved fine dining) but the note from Junior's school (yet again) meant that Roy could not ignore the problem of Junior any more.

Junior chattered away, unrepentant, a bouncy cheer on his chubby face, so scrubbed-clean, an ideal seven year old. Roy kept glancing at him as he drove him back from school. How could Junior just dismiss the scowling principal? Or ignore nanny's head rolling on the floor, its lips muttering, "Good boys don't tell lies."

"Why did you do it?" Roy asked, unable to stop himself.

"Do what?" Junior looked mildly puzzled. "Oh, that stupid nanny. Old version. Head came off so easily, too. The school should get upgrades."

"Your nanny wasn't a clunky metal model, or even an icky-plastic one." That would have been okay. "Nanny was a positronic humanoid." Roy almost added, like you, but Junior didn't know, so he took a deep breath and swallowed the words. "Didn't it hurt you to yank her head off?" Junior's circuits should have stopped him from violating the third law.

"Forget it," Junior said. "Say, will Mom get my PlayStation today?"

Clara. Roy's guts twisted. She would be so unhappy about this.

Six months ago, Clara said: "I want a son."

Beethoven background, her favourite symphony. Dark coffee at her elbow, exactly as she liked it. New chairs, the right softness, the right peach shade. Another perfect evening arranged by Roy. So why this?

"Am I not good enough?" he asked, hurt.

"We'll be a complete family."

"But you'll need surgery."

Clara laughed. "Don't be funny. Constructs are offering discounts if we try their new version."

She chose the age (seven, so toilet-trained, distinct personality), gender (boy, no cutie girl), intelligence (high, of course) and docility (low, because a boy must be a boy, or what's the point?). Roy soaked in her smile, and felt his heart warm up in response.

For past 'family fun-time memories', Clara selected parameters for beach holidays and picnics and auto-generated photo albums. When Roy suggested watching the coded-in past, she laughed. "Seven years' worth? Don't be silly." She collapsed salient memories to a three-day capsule, gave the bot a hazy amnesia for the rest.

Junior arrived.

Clara gave up the pick-him-up-fromschool in a week, the let's-do-homeworktogether in two. She soon tired of Junior's prattle about homework, class bullies and maths lessons. Within a month of Junior's

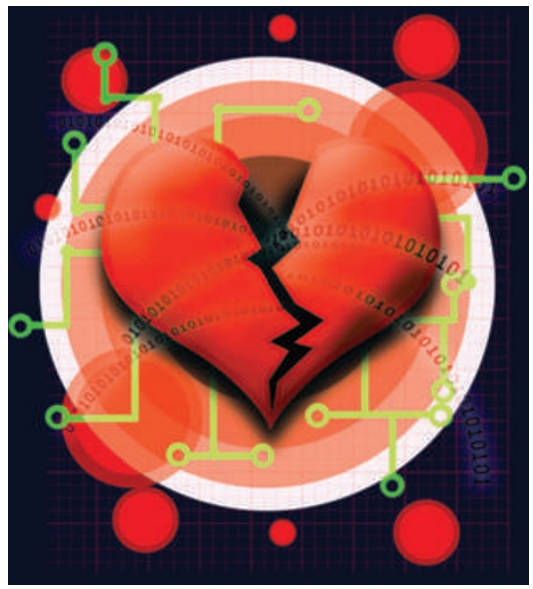

delivery, she shrugged off Roy's updates (and complaints) on their 'son', and reminded him that she needed enough me-time to recharge herself; her job had responsibilities that needed full attention.

Roy suggested 'returning' Junior to Constructs, but Clara sniggered that surely a househusband could handle a small bot? It almost hurt, but he loved her too much to mind for long.

He bought a course on fathering bots.

The law was clear on the nanny episode: boticide by a bot was a severity- 3 deviation; Junior should be reprogrammed or destructed.

Problem was, Clara still loved the concept of Junior. His behavioural lapses were, to her, a failure of her specifications, an embarrassment for a top-notch professional. It was as if, by pretending all was well, they would be the ideal happy family.

Roy squirmed. She shouldn't have requisitioned a high anti-docility.

But he loved her and he wanted her to be happy.

"Junior destroyed a humanoid nanny," he told Clara that evening.

She paled.

"I'm sorry," he said. "I tried my best."

"No, no, not your fault." She flipped on her PDA, entered some codes. "This is awful; I hate it." She got up and began pacing.

That's when Junior walked in, grinning and muddy, holding a soccer ball. Like nothing had happened.

And Roy got a brainwave: he may have failed as father, but he could save Clara some agony now.

If only Junior didn't look so real.

Destructing him - it - was legally allowed - no, required - because a bot had destroyed another.

At times like this, when Roy forced himself to do something he hated because of Clara, he suspected this was not what love should be. Then he thought of her smile.

Clara's PDA lay on the table, with Junior's destruct code on top.

Damn.

Roy fought his nausea and clicked 'Confirm.'

Junior froze, and then slumped, limbs tangled in impossible ways. The ball slipped out of his hands and thumped to the floor. A faint smell of burnt circuitry began spreading.

"Roy?" Clara looked at the awkward arrangement of dismantling body parts, and then at Roy. "Why did you ...?"

Roy wanted to throw up, but he kept his face expressionless; he didn't want to alarm Clara. "Junior was dangerous, but you would have hated destroying him."

Clara blinked rapidly. Her mouth fell open; she closed it.

"Next time, specify less naughtiness, okay?" he said softly.

Tenderness suffused her face. "I really messed up the specifications, huh? So many contradictions."

He blew her a kiss. His head hurt. "It's okay."

"Was it tough destructing Junior?" Clara squeezed his hand. Her gentle, almost wistful smile made the migraine worth it.

"No," he lied.

Pause.

"I love you," he added. That, at least, was true.

"Too much, I think." She sighed. "I loved you."

She hugged him and stepped back. Something glittered in her hand. Her eyes were moist.

"But your circuits didn't work either," she whispered, and everything exploded inside him.

Swapna Kishore is a software consultant in Bangalore, India. She has published technical books and a business novel. She also writes speculative fiction. 